\title{
The Innovation Source of a News Television Business Model
}

\author{
Arina-loana MOGA, PhDc \\ Faculty of Journalism and Mass Communication Studies \\ University of Bucharest, Romania \\ E-mail: arina_moga@yahoo.com
}

\begin{abstract}
The technological revolution altered both the demand-offer ratio and the consumption patterns of media products. The competitive dynamics forced entrepreneurs and managers to rethink business models and led the Romanian news televisions to find new sources of income in order to be able to operate. Media market researchers have found that the traditional business model of television (selling TV advertising) is outdated and recommended the approach to innovation. In Romania, on a market in which there are about 700 televisions, the ones from the news niche compete not only with each other, but try to get the largest share of the revenues earned from television advertising. Shaping a business model in context with the market is necessary for these media organizations in order to become competitive. Romanian news televisions have found sources of innovation in terms of revenue that helps them to operate. This article pursues only the financial component of the business model in an attempt to identify whether there are other sources of income for news televisions than the traditional news ${ }^{1}$.
\end{abstract}

Keywords: News television; Business model; Finance sources; Media market; Innovation.

1 The data presented in this material are part of the doctoral research „Publishing and Marketing Strategies of Romanian Television News" conducted by the author in her capacity as PhD student at the Faculty of Journalism and Communication Sciences, University of Bucharest. 


\section{Introduction}

This article aims to determine if news televisions from Romania have approached innovation in addressing the business model on which it operates. For this approach was selected the main element of the business model - the revenue. The revenue, which is the basis of the business model, contributes to the overall picture of the studied organization. The paradigm accompanying this research addresses the selected media institutions from an economic perspective. The main objective of this academic approach is to identify the existence of new sources of income for these media organizations, which would help them to respond the changes in the market.

The context in which this research is conducted is given by the unprecedented competitive dynamics, which has led to the fragmentation of audiences and has changed the way media products are consumed. However, TV consumption in Romania is growing, with almost double the world average and news stations remain in consumer preferences, ranking the first place.

In addition, the financial value of the media market is rising, the revenues from television advertising ranked first in relation to the rest of the media through which it buys and broadcasts advertising (radio, print, on-line and $\mathrm{OOH}$ ). On this background, competitive dynamics have increased, and the consumption of audiovisual products offered by the news niche has risen to the detriment of general television, as revealing audience surveys. The news stations have grown in top preferences of Romanian consumers since 2014, occupying the first places in the general ranking of national televisions, where ProTV is the leader. However, news televisions have financial difficulties and finding new sources of income would help them survive.

In achieving this research, it was important that until the present moment, there is no published study to address this issue at the level of the Romanian television market. The novelty of this research is given by the approach of the news television niche as a subject of a broad academic approach and the approach of this field from the perspective of the media economy.

Through this approach, we aim to respond to the interest of researchers and practitioners in identifying the strategies that keep news televisions on the market.

The business model of a company traces its commercial activity. One of the elements that stand at the base of the business model architecture is the company's financial model. To it we get to add the beneficiaries or the clients (Kotler, 2000, 105), as well as the value proposition for the client, the key resources and the key processes (Johnson et al., 2008, 60-61). The five developed elements underlie any business model. According to Johnson et al. (2008, 60-61), a major change in one of the five elements affects the others, but the change or the effect is also felt at the level of the whole business model. 


\section{Literature review}

The emergence of the business model concept is associated among researchers with the emergence of the Internet in the mid-1990s (Amit \& Zott, 2001). The first definitions of this concept is outlined by Timmers (1998), who provide a framework that would lead to understanding the concept, even if this approach was focused on e-commerce analysis. The business model was defined as "an architecture of product flow, service and information, including a description of the various business factors and their roles; a description of potential benefits for different business factors; a description of sources of income" (Timmers, 1998, 4). An analysis of the Timmers definition (1998) indicates the reference to elements of the business model, the value chain, even if they are not all presented in the text in the specific terms form: proposal and creation of value, the income.

Innovation is another starting point in conceptualizing the business model. Chesbrough $(2010,354)$ approached the definition of the concept, starting from the statement that business models are commercializing new ideas and technologies. Even though the two elements are within reach of organizations, the researcher has noticed that very few companies have the ability to innovate business models by using them. In the same perspective is included Teece (2010), who amplifies the need to adapt the business model to how the products are delivered and how they capture its value through the delivery of new products and services. Teece (2010, 172) points out the fact that the essence of a business model is given by determining how the organization offers, attracts, and transforms value into profit. A business model "articulates logic and provides data and other evidence" through which it is described the process through which both the consumer and the customer obtain benefits. This concept is also associated with the financial architecture that supports the whole process (Teece, 2010, 173). In Teece's interpretation (2010, 179), a business model is viable if it offers benefits both the client and the company, and benefits of a competitive advantage. The researcher believes that imitating or copying the model by competitors would be avoided by finding or inventing an "isolation mechanism" in the design of the business model, that would lead to establishing a business strategy (Teece, 2010, 180). The author exemplifies the "newspaper revenue model", which was very easy to replicate and implement on thousands of markets around the world. Practically, because of this press model, the newspaper is produced at a low cost, and revenue is collected through the sales of advertising spaces, including advertisements (Teece, 2010, 180).

Picard $(2008,1)$, who has studied the media market for the past 30 years and has defined the way in which the dual-market of televisions operate, characterized the media business model as "worn and scary" more than a decade ago, which was not supposed to be replaced at that time because it was still functional. 
Traditional television business models are associated with a funding system based on: advertising, in the case of free-to-air networks, the revenue coming from advertising and subscription fee in case of the paid the television. The financial model of the free-to-air television is related to the dual market (a term defined by Picard) in which it operates. The media organizations must respond to the audience's demand and needs, but they must also respond to those advertisers' demands who are buying space within the advertising space (dual-market). The value proposition (broadcast grid) offered to consumers (viewers) will be found in the media's company revenue. If the business model of the television does not record other sources of income, the organization will operate only based on advertising revenue.

In designing a new business model, Picard (2008, 8-13) recommends a serious analysis of the current one, while focusing on the quality of the products and the services provided, the allocation of resources, the way of organization, and the value created. The author recognizes that there are no new business models that finance the "limited quality of journalism" (Picard, 2008, 10) and solve the issue of revenue in news organizations. So far, the six possible sources of funding (shareholders, sponsors, foundations, government, advertising agencies, the audience) have been tested in both traditional and on-line media (Picard, 2008, 10-11). The researcher believes that news organizations need to discover new sources of funding and change their business models. Picard $(2011,8)$ claims that the business model highlighted by traditional media has lost its effectiveness and has started to show problems because it is trying to advertise the old types of media products, "19th-century and 20th-century products in the 21st century". The theorist points out the fact that there is no longer the same political, cultural, social and economic context that favors the appearance of traditional media content. In a market with serious competitive dynamics, media institutions need to rethink their business model, in current terms, to stay in the market. These changes are more than necessary for media organizations to respond competitively to the changes that emerged in the last 20 years, requiring new sources of income or strengthening the existing ones (Picard, 2011, 8).

\section{Methodology}

The main objective of this research is to determine whether news televisions use innovation in their business model on which they operate. This article tracks the revenue sources of news televisions, the main element of the business model. Also, the practices used by these media organizations to ensure the required financial performance are being pursued in this research.

In order to achieve the main objective of the paper, the following main research question was used: Are the new sources of income an innovative element of the business 
model? A secondary question: Is the revenue source, as a component of the business model, a differentiation element in the positioning strategy of these organizations on the news television market?

In order to collect the data needed to achieve the objectives, this paper aims to use the case study, considered a useful tool of the empirical investigation, which attempts to clarify a decision or a set of decisions (Yin, 2005, 27-29). As a research strategy, the case study has a comprehensive approach that includes design logic, data collection techniques, and some specific approaches to their analysis (Yin, 2005,31 ). Applied to this research the case study will be focusing on analyzing five television newscasts in Romania: Antena 3, B1 Tv, Digi24, Realitatea TV, Romania TV from the perspective mentioned above. Several criteria have been taken into account in the selection of the televisions for this research: thematic area (general news), coverage (national), and ownership form (private). The five news channels - Antena 3, B1 TV, Digi 24, Realitatea TV, Romania TV - were monitored during the period 2015-2017, in which all these media organizations were part of the audience measurement program developed by Kantar Media.

In order to see on what type of business model the television in the informative niche operates, all sources of income had to be identified. The public information displayed on the websites of public institutions was studied: ANAF, Ministry of Finance, S.E.A.P. (The Public Electronic Procurement System) ${ }^{1}$, but also information that were public on the five official pages of the televisions concerned by this research were also studied.

\section{Results}

Through studying these public sources, several revenue streams in the five news televisions were identified. The description starts from the source considered the traditional business model adopted by the televisions around the world, the advertising broadcast in the specific program grid.

\section{A. The revenue from advertising \\ a) TV advertising}

The traditional TV business model is based on revenue from broadcast advertising. The level of the Romanian advertising market has increased exponentially in the last few years, from 212 million Euros in 2015 to 273 million Euros in 2017, according to the Media Fact Book (Initiative, 2018). In addition, in these years, television ranked first in the preferences of advertisers, at a considerable distance from the rest of the media that buys and distributes advertising. In 2015, television

1 Through this platform, public institutions from Romania are required to conduct purchases of products or services. The system was introduced in 2006 and had the role of increasing transparency in the procurement process. 
accounted for $64 \%$ of total revenue from media advertising, $65 \%$ in 2016 , and $66 \%$ in 2017 (Initiative, 2018). For these estimations, radio, print media, on-line media, and billboards $(\mathrm{OOH})$ have also been taken into consideration.

The five news stations collected 20-21 million Euros in 2017 from advertising spots only (Initiative, 2018). For these estimations, the amounts received from teleshopping or product placement were not taken into account. Even though Antena 3 and Romania TV have been sanctioned by customers who had decided to withdraw their advertising due to editorial slippages recorded in protest coverage (against OUG 13) since the beginning of 2017, the two stations ranked first in the revenue score from the classic advertising, according to the same sources.

Table 1. The revenue from advertising for news television (Obae 2018)

\begin{tabular}{lc}
\hline & $\begin{array}{c}\text { The revenue fom advertising } \\
\mathbf{2 0 1 7}\end{array}$ \\
\hline Antena 3 & $\mathbf{7}-\mathbf{8}$ mill Euros \\
B1 TV & $4,5-5,2$ mill Euros \\
Digi24 & $4,5-4,8$ mill Euros \\
Realitatea TV & 3 mill Euros \\
România TV & $1,8-2,2$ mill Euros \\
\hline
\end{tabular}

\section{b) Advertising on the website}

Collected data indicates that news televisions also earn revenue from selling advertising spots on their official websites: antena3.ro, b1tv.ro, digi24.ro, realitatea.net, romaniatv.net. For the analyzed period of time, four of the five websites show abundance in advertisements, while Digi24 channel website only contains advertising on RCS-RDS products that manage the television, such as the mobile service Digi Mobile. Regarding the fact that the products and services are of the same group, we can not conclude with certainty that their advertising on the digi24.ro website was made by paying the space occupied, and in this situation the barter system could also be taken into account.

\section{B. Video site content}

From analyzing the on-line websites of news television, it was revealed that the broadcasts of Antena 3 could only be re-watched, only on the video platform of the Intact trust, Antena Play - www.antenaplay.ro. Access to news station reps is done by paying a monthly subscription that is about 3 euro / month + VAT. For the rest of the news television, access to the broadcast content was free but also limited to a period of time, because tese products were archived (up to a month).

\section{Airing for the promotion of European funds projects}

With the financial exercises of the European Structural Funds, the promotional component created an opportunity for media organizations, especially the tradi- 
tional ones, to gain. The flexibility of the program structure of news televisions, to the detriment of the generalists, has created this opportunity to attract a new source of funding. Adapting the program grid to the ongoing events has made it possible to host and implement this type of program, either live/on-air or as a record. The production and hosting of these productions were charged with a fee, with the morning broadcasting facilities being contracted. Within these programs, projects that ran on European funds were promoted by inviting the project manager or another representative involved in the program to the studio.

\section{Public money contracts}

Another source of revenue for the news televisions during the monitored period of time was the one obtained from the contracts concluded with the state institutions. In order to be able to access these funds, the media organizations participated in an auction system, made by S.E.A.P.

From consulting the website www.e-licitatie.ro database, it appeared that news televisions provided specialized services to institutions that were looking for it. The data collected showed that Antena 3 benefited from public money obtained from the City Hall of district number 4, Bucharest, through contracts awarded through a direct award without an auction. For the monitored period of time (2015-2017), S.C. Antena 3 S.A., the company that manages the television with the same name, has two contracts for "television advertising media services" (www. demo.e-licitatie.ro) worth 44,800 Ron (9,822 Euros) and 111,300 Ron (24,372 Euros) respectively. The value in euro is calculated by the auction system at the time of the contract award.

One of the contracts earned by the company managing the news television of the Intact Media group (date of direct award: June 15, 2017) refers to "the design, production and the broadcasting of informative materials about the work done by the beneficiary" (www.e-licitatie.ro), which is, the City Hall of the district. From analyzing the data displayed on the e-licitatie.ro platform, it was revealed that Antena 3 provided video production services (filmed, mounted), the broadcasting of these productions, and also monitoring them. The second contract won by Antena 3 for media advertising on television (date of direct award: June 12, 2017) has as aim, transcription services for radio-TV interviews, press statements, or press conferences held by representatives of City Hall district number 4 .

Another media organization that has earned public money through the same platform is Realitatea TV. In 2016 they also received a direct contract from the City Hall district number 5, a contract that aimed at developing "media coverage, production and broadcast daily TV ads to inform residents about the organization of an event of public interest." (Antena 3, preferata lui Baluta,, 2017). The amount of money awarded to Realitatea TV at that time was 60.000 Ron. 
For the period under investigation, 2015-2017, only two of the five news televisions used the S.E.A.P. to get new revenue generating contracts: Antena 3 and Realitatea TV.

\section{E. Electoral advertising on the on-line platforms}

After consulting the official website pages of the five news televisions, another source of income was found for one of the media organizations under investigation. B1 TV has used their on-line platform to get an income from the electoral advertising of the 2016 local electoral campaign. B1 TV's management has resorted to this strategy because of the fact that in the traditional audiovisual media, C.N.A. ${ }^{2}$ has banned the broadcasting of paid electoral advertising. Elements of the on-line electoral campaign advertising were both products found in the traditional media (video-interview, live broadcast, advertorial, spot) and other on-line media products (ex: banner display). This revenue source identified by B1TV management has been used for a short period of time, up to two months during the electoral campaign.

\section{Discussion and conclusion}

Preliminary results from this study of public sources have indicated that the five news televisions undergoing this research have approached several directions in order to obtain the extra revenue needed for its operation. Antena 3 has accessed most of the additional funding sources, followed by B1 TV, Realitatea TV and Romania TV. The main source of income characteristic of the traditional business model, broadcast advertising has been found in all media organizations undergoing this research. In parallel with this source, the data gathered indicated the interest of thematic television management in finding new financing paths to ensure the conduct of the business. The publicity contracted on the official websites of the studied televisions, the realization and broadcasting of projects promoted by European funds, the public money contracts awarded through S.E.A.P. platform, were approached by the majority of the organizations studied.

Two of the studied organizations, Antena 3 and B1 TV, have differentiated themselves by addressing other revenue streams. Intact TV has chosen to sell live video content online, as well as its video archive online, while B1 TV has monetized the content of the electoral campaign online for a short period of time.

Competitive dynamics forces the management of media institutions to adapt their business model and identify other sources of income to support their opera-

2 The National Audiovisual Council of Romania (C.N.A.) is the regulator for the audio visual sector in Romania. According to the legislation, CNA is an autonomous public institution who ensures that the television and radio stations operate „in an environment of free speech, responsibility and competitiveness" (www.cna.ro) 
tion. The practices used by the five news televisions have shown that the organizations have used innovation to address the business model on which they operate, that responded positively to the primary objective of this approach. The revenue source of news televisions can be considered an innovative element of the business model, and in some cases (Antenna 3, B1TV) can also be considered as a differentiation in the strategy of positioning these organizations on the market. Following the analysis of the results, we can conclude the fact that there is a replicaton trend at this level of the business model among the five studied news televisions.

The assumption of innovation in addressing the business model and recourse to new practices, confirms that these niche televisions need new sources of income to strengthen the existing ones, as Picard anticipated (2011). The decision-makers in these organizations have found that the traditional business model based only on television advertising revenue is no longer sufficient to support the business. Even if the traditional source of funding remained the advertising purchased on the basis of the audiences of the broadcast programs, other new funding opportunities were identified as viable. The need to adapt the business model highlighted by Teece $(2010)$ and Picard $(2008,2011)$ can be found in news niche televisions in search of new products and services to deliver benefits for both parties, the consumers and the organization.

However, not in all cases, viewers have been tangled with the new products or services that the media institution has launched. In the case of public money contracts obtained through direct award, through S.E.A.P. platform, the beneficiaries of the services provided by the news televisions (Antena 3, Realitatea TV) were, in some cases, the district City Halls mentioned above. On the other hand, the electoral products broadcast by B1 TV on-line (website, Facebook) could only be seen by those who attend this information dissemination environment.

Addressing innovation in the business model is beneficial to news televisions and it opens up the opportunity to shape new products and services from which the organization can earn revenue. These changes, considered necessary by Picard (2011), will prove to be helpful in the cases where traditional advertising were to be reduced for different reasons (economic and financial, poor ratings generated by the quality of the broadcasted programs) or is stopped from broadcasting at the request of the advertisers or the clients (e.g. the editorial slips registered in the OUG 13 protest report in early 2017). While news televisions will rely heavily on revenues associated with traditional business models (TV advertising), their activity may suffer, as was the case with Romania TV (delays in paying employees, mass departures from the editorial board).

This approach encountered limitations due to the nature of commercial data, so that the level of additional funds obtained by the five news televisions could not be determined. If there are some official estimates of the revenue obtained by 
each television for the traditional source of revenue (TV advertising) associated with the classic business model, no new calculation can be done for the new revenue sources because of the confidentiality of commercial data. However, based on the collected public data, we believe that the level of revenue generated by the broadcasting of the programs is still the main source of funding for these media organizations. Also, for the next period of time, it is possible to anticipate an increase of these values for the news niche leaders (Romania TV and Antena 3) taking into account the level of the amounts registered on the TV advertising market, which is constantly increasing in the last years. The estimation is also based on the fact that the two mentioned news televisions have climbed to the top of the Romanian televisions, occupying places in the top part of the ranking (4-5).

This article provides a clear insight into the business model of Romanian news televisions and indicates that innovation offers these media organizations the chance to attract more revenue sources, that would help them respond to market changes. The result open new ways to study the news television market from the perspective of media economics.

\section{References}

1. Amit, R. \& Zott, C. (2001). Value creation in e-business. Strategic Management Journal, 22, 493-520.

2. Cerban, M. (2012, May 24). STATISTICĂ: Câte televiziuni şi radiouri sunt în România. Mediafax. Retrieved January 10, 2018 from: https:/www.mediafax.ro/ cultura-media/statistica-cate-televiziuni-si-radiouri-sunt-in-romania-9667326.

3. Chesbrough, H. (2010). Business Model Innovation: Opportunities and Barriers. Long Range Planning, 43, 354-363.

4. Initiative. (2018). Media Fact Book Romania 2018. Retrieved November 23, 2018 from: http://www.mediafactbook.ro/public/files/MFB2018.pdf.

5. Johnson, M. W., Christensen, C. M. \& Kagermann, H. (2008). Reinventing your business model. Harvard Business Review, 57-68. Retrieved January 3, 2018 from: https://s3.amazonaws.com/academia.edu.documents/38668596/HBR_on_Strategy. pdf?AWSAccessKeyId=AKIAIWOWYYGZ2Y53UL3A\&Expires=1521707776\&Sign ature=YI4bPG\%2FyGXLEH0wiWxZ\%2FZcqtdaI\%3D\&response-content-dispositio $\mathrm{n}=$ inline\%3B\%20filename\%3DForces_That_Shape_Competition.pdf\#page $=57$.

6. Kotler, P. (2000). Managementul marketingului, Analiză, Planificare, Implementare, Control. ( $8^{\text {th }}$ ed.). Bucharest, Teora.

7. Obae, P. (2018, January 16). Câți bani au scos din reclame posturile de știri: în jur de 25 de milioane de euro toate. Cum s-a simțit boicotul la RTV și Antena 3. Digi, cel mai scump. Pagina de Media. Retrieved April 6, 2018 from: https://www.paginade media.ro/2018/01/cati-bani-au-scos-din-reclame-posturile-de-stiri-20-de-milioanetoate-cum-s-a-simtit-boicotul-la-rtv-si-antena-3-digi-cel-mai-scump. 
8. Picard, R. G. (2008). Business Models for News: Worn, Frayed and in Need of Repair. The Carnegie-Knight Conference on the Future of Journalism, Cambridge, MA.

9. Picard, R. G. (2011). Mapping Digital Media: Digitization and Media Business Models. Reference series no. 5, Open Society Foundation.

10. Teece, D. J. (2010). Business Models, Business Strategy and Innovation. Long Range Planning, 43, 172-194.

11. Timmers, P. (1998). Business models for electronic market, Electronic Markets, 8(2), 3-8. Retrieved February 12, 2018 from http://www.electronicmarkets.org/fileadmin/ user_upload/doc/Issues/Volume_08/Issue_02/V08I2_Business_Models_for_Elec tronic_Markets.pdf.

12. Yin, R. K. (2005). Studiul de caz. Designul, analiza și colectarea datelor. Iași, Polirom.

13. LEGE No. 504 (2002, July 11). Legea audiovizualului. Retrieved February 12, 2017 from: http://www.cna.ro/IMG/pdf/LEGEA_AUDIOVIZUALULUI_CU_MODIFIC ARI_SI_COMPLETARI_DIN_2014.pdf.

14. Wall Street (2017, August 3). Antena 3, preferata lui Baluta: doua contracte de aproape 200.000 de lei, din bani publici. Retrieved April 5, 2018 from: https://www. wall-street.ro/special/sublupa/212948/antena-3-preferata-lui-baluta-doua-con tracte-de-aproape-200-000-de-lei-din-bani-publici.html.

15. www.antena3.ro

16. www.b1.ro

17. www.cna.ro

18. www.digi24.ro

19. www.e-licitatie.ro

20. https://www.intactmediagroup.ro

21. www.licitatiiseap.ro

22. www.realitatea.net

23. www.romaniatv.net 